\title{
MAPPING OF STRIP FOREST IN ADAMPUR RANGE (HARYANA) A GEO-INFORMATICS APPROACH
}

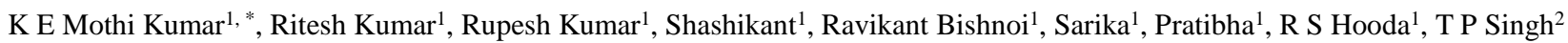 \\ ${ }^{1}$ Haryana Space Applications Centre (HARSAC), CCS HAU Campus, Hisar, India - kemk@ rediffmail.com \\ ${ }^{2}$ Conservator of Forests, Haryana Forest Department, Van Bhawan, Panchkula, India
}

Commission V, SS: Natural Resources Management

KEY WORDS: Strip Forest, Forest Mapping, Social Forestry, HRS - WV, Smart GIS \& Decision Support System.

\begin{abstract}
:
Haryana state is an intensively cultivated state, and deficient in natural forests. One of the mandate of Haryana Forest Department (HFD) is to afforest for maintenance of environmental stability and restoration of ecological balance affected by serious depletion of forests, woodlands and water, and to increase tree cover in the state. National Forest Policy (1988) has set a goal to bring one third of Country's area under forest and tree cover. Stock and dynamics of Trees Outside Forests (TOF) along with natural forests need to be understood holistically to appreciate the ecosystem services e.g., timber and non-wood products as tangible benefits along with services like carbon, water and weather moderation. The present study has attempted to demonstrate the utility of High Resolution Worldview- II (WV) satellite data (ortho rectified) that offeres immense scope to analyze the strip forests in Hisar district (Haryana, India). The study area Adampur Range (Hisar District) lies between the north latitudes $29^{\circ} 0{ }^{\prime} 52.229^{\prime \prime}$ to $29^{\circ} 25^{\prime} 6.746^{\prime \prime}$ and east longitudes $75^{0} 14^{\prime} 0.266^{\prime \prime}$ to $75^{\circ} 45^{\prime} 11.093$ " with a total geographical area of about 1092.04 sq. km. The adopted methodology involves onscreen digitization of the strip forest areas in the Adampur range (Hisar Distirct). The ToF formation identification and delineation includes the forest land besides roads, river, streams, canals, distributaries and railway lines etc. The shape files were converted into. $\mathrm{kml}$ files and overlaid on the Google Earth data for validation. An attempt has been made to compare the area difference between the Haryana Forest Department (HFD) notification details with that of the digitized strip forest lands. It was observed that the surveyed forest area is found to be 1717.37 ha. against the notified forest area of 1714.45 ha. showing a difference of 2.92 ha. approximately in the studied beat boundaries.
\end{abstract}

\section{INTRODUCTION}

The role of trees within landscapes has been given much attention recently, in contexts ranging from local watersheds to regional impacts and global cycles. As an example, trees, forests and reforestation are specifically identified as viable climate change mitigation measures by the Kyoto Protocol, but have also been identified both as carbon sinks and sources. It is evident that widespread and continuing deforestation has significantly reduced the extent of forests globally and across the tropics.

Social forestry exists not only in the context of forest deterioration but is also integrally linked with a number of macro- and micro-level socioeconomic and ecological facts and parameters can be grouped into the following factors: (a) low per capita landholdings, (b) reduction of effective tree cover, (c) the rising gap between demand and supply, (d) massive deforestation, and (e) distribution issues. (Huq \& Alim, 1995).

The FSI has made a comprehensive assessment of TOF in rural and urban areas of Punjab using remote sensing techniques followed by a field inventory. TOF provide a viable diversification option and help in making farm management practices competitive, which is desirable in the present era of globalization. TOF also help in achieving ecological security by improving soil and water conservation. With an increasing focus on the development of rainfed areas and diversification of agricultural practices, economic theory about traditional practices is also becoming increasingly prevalent. In these circumstances, the prospects of perennial tree-based crops including agroforestry have a significant future. This is complemented by increasing government efforts and several

${ }^{*}$ Corresponding author initiatives by the private sector for networking with farmers on production systems related to pulpwood, plywood, biofuels, bamboo, etc. Thus, while agricultural developments put pressure on forestry in terms of area, they can also reduce pressure on forests for wood based products; the area supporting perennial tree-based systems could only add to green cover. (Sharma. Abhimanyu.2015).

Haryana is an agriculture based state with a total geographical area of 44,212 sq. $\mathrm{km}$. out of which $1,559 \mathrm{sq}$. km. is under forest areas. Forestry activities in the state are dispersed over the rugged Shiwalik Hills in the North, Aravalli Hills in the South, sand dunes in the South-West, other wastelands and water-logged, saline and alkaline soils in the central part of the state. Against the revised National Forest Policy (Ministry of Environment, Forest and Climate change, 1988) of maintaining forest cover over one - third of the area, only $3.53 \%$ of the total geographical area in Haryana has been notified as forest area. (FSI, Report. 2017).

\section{STUDY AREA}

Adampur range lies between the north latitudes $29^{\circ} 0^{\prime} 52.229^{\prime \prime}$ to $29^{\circ} 25^{\prime} 6.746^{\prime \prime}$ and east longitudes $75^{\circ} 14^{\prime} 0.266^{\prime \prime}$ to $75^{0} 45^{\prime} 11.093$ " with a total geographical area of 1092.04 sq. km. The study area falls in Yamuna sub-basin of Ganga basin. There is no natural drainage in the area. However, the area is drained by network of canals and the artificial drains (field drains/channels). Climate of the study area is arid and hot which is mainly dry with very hot summer and cold winter except during monsoon season when moist air prevails. The summer starts from mid March to last week of the June followed by the south- west monsoon which lasts till September. The transition period from September to October forms the post-monsoon season. The winter season starts late in November and remains 
up to first week of March. The normal annual rainfall is 373 $\mathrm{mm}$. About $80 \%$ rainfall occurs in monsoon season and $20 \%$ rainfall is received during winter in the wake of western disturbances. During winter i.e. January and February, the temperature goes down below $1^{\circ} \mathrm{C}$. (CGWB.2013). The location map of the study area is shown in figure-1.

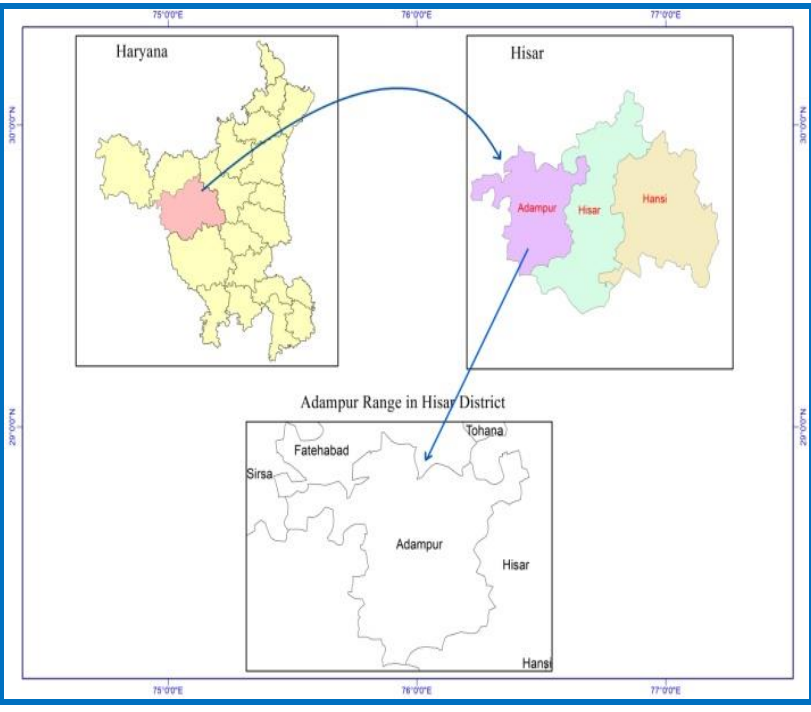

Figure 1. Location map of study area

\section{DATABASE AND METHODOLOGY}

\subsection{Data sets used}

\section{(a) Satellite Imagery}

High resolution ortho-rectified World-View-II panchromatic image with $0.50 \mathrm{~m}$ resolution of 2011 was used for the study area.

\section{(b) GPS Data}

Garmin GPS navigation receiver was used for GCPs collection of strip forests starting point and ending point for each strip.

\section{(c) Notification Data}

The notification details (width \& length) for strip plantation of the study area was provided by the Haryana Forest Department (HFD) and used for identification and fixing the length of the strip plantation.

\subsection{Methodology}

The present work elaborates the geospatial techniques to create the spatial database for strip forest mapping and this approach goes through several stages.

1. The first step deals with the digitization of line network (Roads, Canals, Drainage \& Rail) on ortho-rectified World View-II data on 1:2000 Scale by using onscreen digitization techniques.

2. The Second step deals with the collections of GPS reading for the strip from the start point and end point to fix the length of the strip plantation.

3. The third step of the work deals with the interlinking of HFD notification data with line network dataset.

4. In the fourth stage the buffer was created on both side (left $\&$ right) by given width as per notification details. The final stage of the work was to overlay the buffer shapefile on
Google Earth and is converted to $\mathrm{kml}$. The flow chart of Methodology is shown in figure-2.

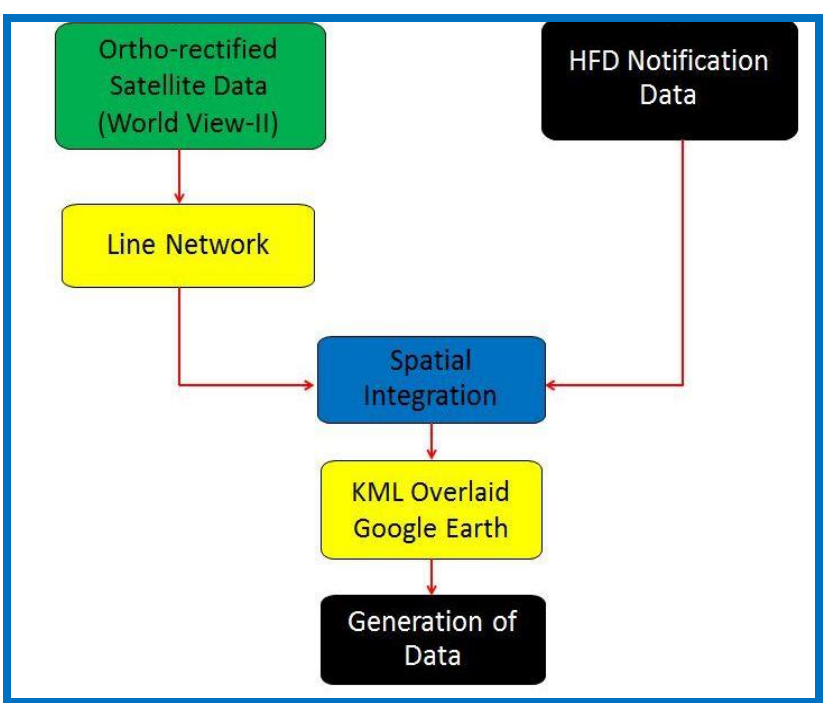

Figure 2. Methodology flow chart

\section{RESULTS AND DISCUSSIONS}

\subsection{Results}

The interpretation of WV Satellite data on 1:2000 scale has helped in delineation of various linear features such as roads (pacca / kachha), drains and railways lines etc.

\section{(a) Line Network Database}

Line network (National Highway, State Highways, District Highway, City Road and Village roads), Canals (River, streams, main canals, distributaries etc.) and Railway lines (Broad gauge, meter gauge etc.) were digitized of entire range. The linear features coding schema was adopted from SIS-DP (Space Based Information Supports for Decentralized Planning) NRSC manual (2011) for the study, as shown in table-1.

\begin{tabular}{|c|c|c|c|}
\hline S. No. & RD type & Status & $\begin{array}{l}\text { RD } \\
\text { Code }\end{array}$ \\
\hline Road & $\begin{array}{l}\text { Pacca Road } \\
\\
\text { Kachha } \\
\text { Road }\end{array}$ & $\begin{array}{l}\text { 1. National } \\
\text { Highway } \\
\text { 2. State Highway } \\
\text { 3. District Highway } \\
\text { 4. City Road } \\
\text { 5. Village Road } \\
\text { 1.Village Road } \\
\text { 2.Cart Road }\end{array}$ & $\begin{array}{l}\text { TPPN } \\
\text { TPPS } \\
\text { TPPD } \\
\text { TPPC } \\
\text { TPPV } \\
\\
\text { TPKV } \\
\text { TPKC }\end{array}$ \\
\hline Drainage & & $\begin{array}{l}\text { 1. River } \\
\text { 2. Stream } \\
\text { 3. Main Canal } \\
\text { 4. Branch Canal } \\
\text { 5. Distributory } \\
\text { Canal }\end{array}$ & $\begin{array}{l}\text { DRRV } \\
\text { DRST } \\
\text { CANM } \\
\text { CANB } \\
\text { CAND }\end{array}$ \\
\hline $\begin{array}{l}\text { Railway } \\
\text { Lines }\end{array}$ & & $\begin{array}{l}\text { 1.Broad gauge } \\
\text { 2.Meter gauge }\end{array}$ & $\begin{array}{l}\text { TPRBG } \\
\text { TPRMG }\end{array}$ \\
\hline
\end{tabular}

Table 1. Classification schema for Line features

The line features (road, canals \& drains) were digitized in the center of the features and the length of the strip was fixed with the help of start and end GPS point of the strip. The digitized road strip in- between Agroha to Adampur with line features 
metadata (code, line status, line type \& length) as shown in figure-3.

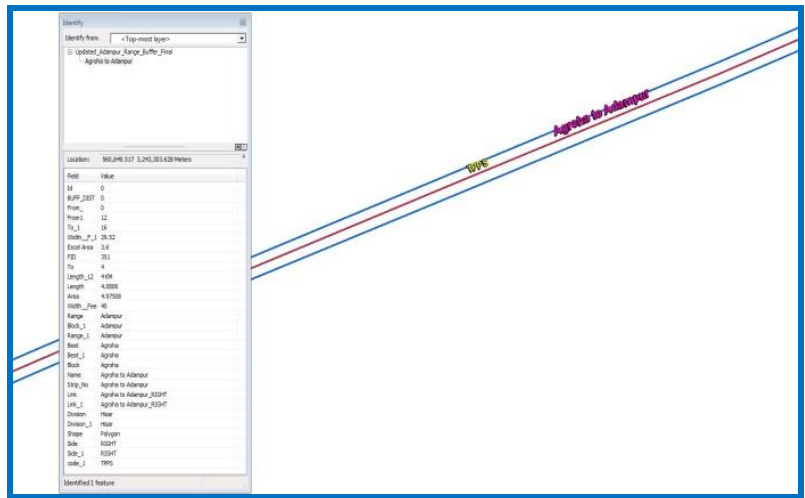

Figure 3.

\section{(b) Buffer Creation}

Buffer creates a new coverage of buffer polygons around specified input coverage features. Features can be polygons, lines, points, or nodes. The buffer tool was used to identify or define area within a specified distance around a feature wise buffer was created for entire Adampur range with the given width in HFD notification and interlinked with notification details provided by the Forest Department. The centre of the line network was taken as the bench mark to calculate the width and buffer creation of the strip forest. The digitized road strip in between Agroha to Adampur with attributes overlaid on the HRS - WV data after the buffer is shown as figure - 4 .

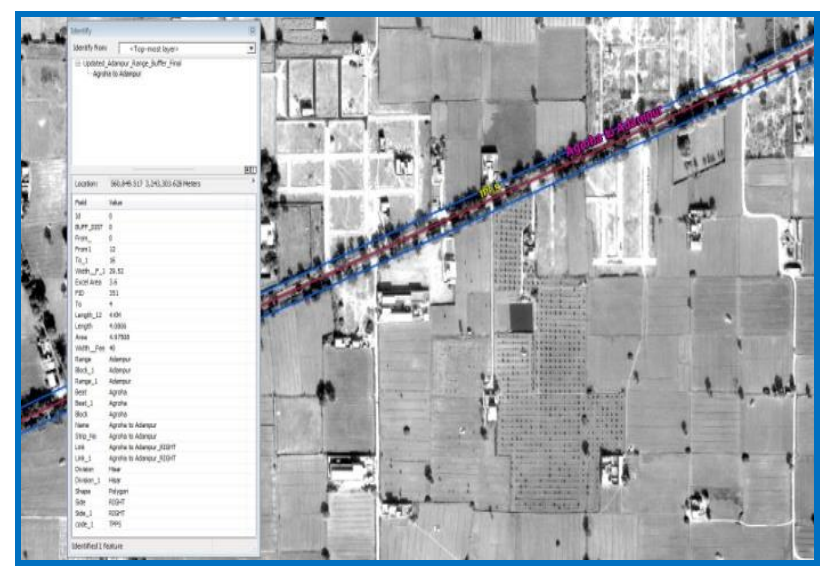

Figure 4. Vector Layer (Buffer) overlaid on WV Data

\section{(c) Analysis of Data}

The analysis for entire 14 beats of the Adampur range was generated and the shapefile converted into the $\mathrm{kml}$ files by using conversion tools box in Arc map 10.0 version. Data was overlaid on Google Earth as final output and was ascertained quality check. The digitized road strip in- between Agroha to Adampur with Attributes (Division name, range, beat, strip, side (left \& right), notification length, width, area, vector length \& area ) overlaid on Google Earth is shown in figure-5.

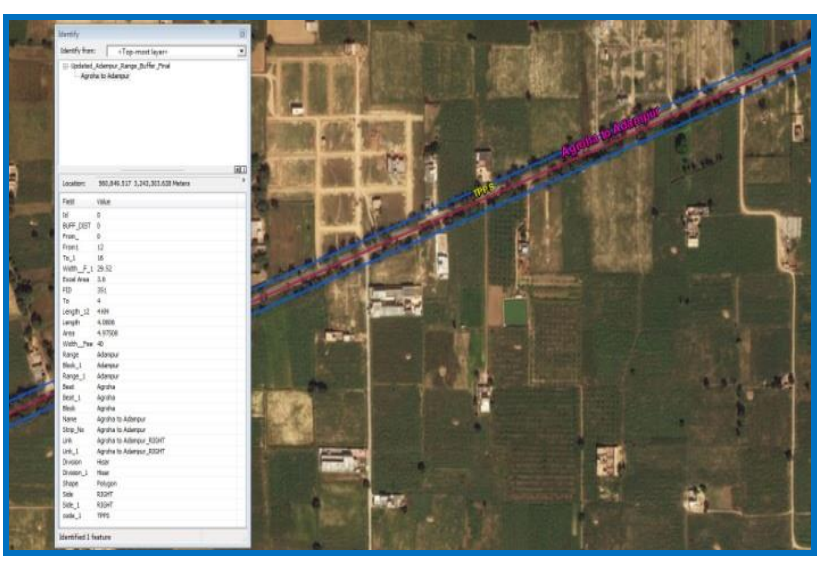

Figure 5. kml files overlaid on Google Data

\subsection{Discussions}

This study introduces an integrated approach for strip forest mapping using geo-informatics techniques. It was found in the study that the area and width of strip was mostly matching with the HFD notification data and hence geoinformatics apporch qulifies for such study.

The corresponding areas of vector files and notification files for strip plantation are shown in Table 2. It was observed that in case of entire range of Adampur, an area of about 1717.37 ha. (digitized area) against the HFD notified area of 1714.45 ha. This difference was occurred because of the length of the roads may be taken from PWD \& BR department in the notification; whereas the start and end point of each strip was taken from starting point of plantation on the ground. In case of beat wise the major difference in area decrease was observed in Nayoli, Balsamand and Kirori. The Nayoli beat, an area of about 213.72 ha. against the HFD notified area of 237.6 (23.8 ha. difference), Balsamand beat, an area of about 125.44 ha. against the HFD notified area of 138.06 (12.62 ha. difference) \& Kirori beat an area of about 79.44 ha. against the HFD notified area of 86.82 (7.38 ha. difference). In case of beat wise increase in area was observed in Jagan, Shiswal and Arya Nagar. The Jagan beat, an area of about $170.68 \mathrm{ha}$. against the HFD notified area of 157.42 (13.26 ha. difference), The Shiswal beat, an area of about 134.52 ha. against the HFD notified area of 123.38 (11.1 ha. difference) and Arya Nagar beat, an area of about 96.66 ha. against the HFD notified area of 88.88 (7.78 ha. difference), whereas in case of beat area almost same was observed in Siwani Bolan. The Siwani Bolan beat was having an area of 69.85 ha. against the HFD notified area of 69.5 (0.35 ha deference). However the overall area difference is found to be 2.92 ha. only. During the field verification, it was also observed that some strips were mentioned in the notification was physically not present on ground. For example the Hisar Major canal mentioned in the notification was not found on ground as shown (photo-1).

\section{CONCULSION}

The present study demonstrates the advantages and capability of geo-informatics techniques for mapping of strip forest on large scale. The generated data will be useful for forest administrators / planners to simplify the decision making, planning and assessment process in a more scientific and logical manner. 


\section{ACKNOWLEDGEMENTS}

The financial grant rendered by Haryana Forest Department, Haryana and the help rendered by the CF (T), DFO and other field officers during the ground truth survey is thankfully acknowledged.

\section{REFERENCES}

Huq, M. F., \& Alim, A. (1995). Social forestry in Bangladesh: State of art study. Dhaka: Bangladesh Agricultural Research Council \& Winrock International.

Central Ground Water Board report of Hisar district (2013), PP.6-7.

Forest Survey Report of 2017, PP.189.

Review of Annual Administrative Report of Haryana Forest Department for the year 2015-16.

Sharma. Abhimanyu. (2015). Mapping of agro-forestry and horticulture plantations in bist doab track of punjab using remote sensing and GIS, master degree thesis, Department of Soil and Water Engineering, College of Agricultural Engineering \& Technology, Punjab Agricultural University, PP.2.

Space Based Information Supports for Decentralized Planning Manual, NRSC-2011, PP.49-52

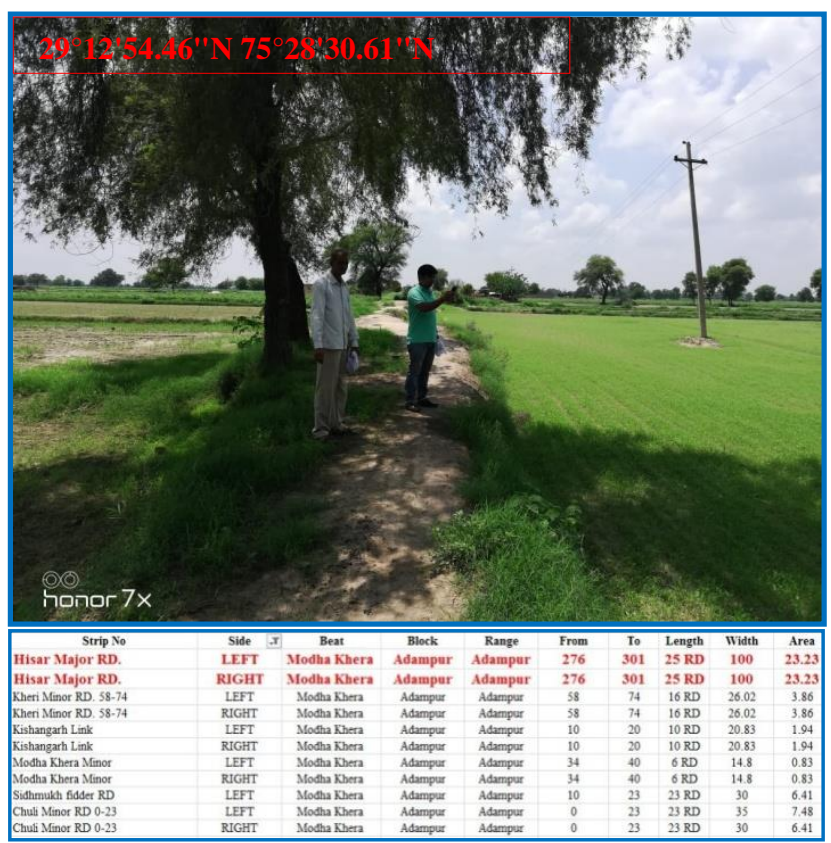

Photo 1. Hisar Major Canal (Modha Khera Beat) mentioned in notification, not present on ground 
The International Archives of the Photogrammetry, Remote Sensing and Spatial Information Sciences, Volume XLII-5, 2018 ISPRS TC V Mid-term Symposium "Geospatial Technology - Pixel to People", 20-23 November 2018, Dehradun, India

\begin{tabular}{|c|c|c|c|c|c|c|c|}
\hline \multirow[t]{2}{*}{ S.No } & \multirow[t]{2}{*}{ Beat Name } & \multicolumn{2}{|c|}{ Length (km.) } & \multicolumn{2}{|c|}{ Area (ha.) } & \multicolumn{2}{|c|}{ Difference } \\
\hline & & $\begin{array}{c}\text { HFD } \\
\text { Notification } \\
\end{array}$ & $\begin{array}{c}\text { Vector } \\
\text { layer }\end{array}$ & $\begin{array}{c}\text { HFD } \\
\text { Notification } \\
\end{array}$ & $\begin{array}{l}\text { Vector } \\
\text { layer }\end{array}$ & $\begin{array}{c}\text { Length } \\
(\mathbf{k m})\end{array}$ & Area (ha.) \\
\hline 1 & Kirori & 108.8 & 102.22 & 86.82 & 79.44 & -6.58 & -7.38 \\
\hline 2 & Agroha & 126.9 & 125.13 & 153.16 & 149.31 & -1.77 & -3.85 \\
\hline 3 & Pabra & 105.7 & 111.92 & 68.78 & 72.44 & 6.22 & 3.66 \\
\hline 4 & Siwani Bolan & 118.02 & 120.58 & 69.5 & 69.85 & 2.56 & 0.35 \\
\hline 5 & Adampur & 129.5 & 133.2 & 122.4 & 119.4 & 3.69 & -3 \\
\hline 6 & Shiswal & 160 & 174.48 & 123.38 & 134.52 & 14.4 & 11.1 \\
\hline 7 & Balsamand & 211.4 & 205.92 & 138.06 & 125.44 & -5.48 & -12.62 \\
\hline 8 & Bhiwani Rohila & 168.5 & 163.8 & 101.66 & 104.5 & -4.7 & 2.84 \\
\hline 9 & Nayoli & 261.8 & 239.3 & 237.6 & 213.72 & -22.5 & -23.88 \\
\hline 10 & Arya Nagar & 153.9 & 162.3 & 88.88 & 96.66 & 8.4 & 7.78 \\
\hline 11 & Kalirawan & 181.8 & 185.14 & 168.16 & 176.04 & 3.34 & 7.88 \\
\hline 12 & Bhoria Bishnoia & 124.24 & 123.88 & 97.89 & 105.94 & -0.36 & 8.05 \\
\hline 13 & Jagan & 194.7 & 208.5 & 157.42 & 170.68 & 13.8 & 13.26 \\
\hline 14 & Modha Khera & 140.29 & 140.26 & 100.74 & 99.43 & 0.03 & 1.31 \\
\hline & Total & 2185.55 & 2196.63 & 1714.45 & 1717.37 & 10.99 & 2.92 \\
\hline
\end{tabular}

Table. 2. Comparison of Strip vector area with HFD notification 